\title{
Pengaruh Ukuran Wadah Kemasan Mika Terhadap Kualitas dan Umur Simpan Buah Stroberi (Fragaria sp.)
}

\author{
YONATHAN CHRISTIAN SIMATUPANG, MADE SUDIANA MAHENDRA, DAN \\ ANAK AGUNG GEDE SUGIARTA*)
}

\author{
Program Studi Agroekoteknologi Fakultas Pertanian Universitas Udayana \\ Jl. PB. Sudirman, Denpasar 80231 Bali \\ ${ }^{*}$ E-mail: aagdsugi@gmail.com
}

\begin{abstract}
Influence of Mica Packaging Container Sizes on Quality and ShelfLife of Strawberry (Fragaria sp.). This study aimed to determine the effect of plastic mica container size with a total of 15 pieces of packaging and determined the best treatment for the shelf life of strawberries (Fragaria sp). This study useds a complete randomized design methodology (CRD) with one treatment, namely the type of plastic mica container size with various types of packaging types as follows: type $1\left(\mathrm{~K}_{1}\right)$, type $2\left(\mathrm{~K}_{2}\right)$, type $3\left(\mathrm{~K}_{3}\right)$ and number 15 fruit packs. The observed variables were weight loss, hardness level, shelf life, organoleptic test, respiration rate and vitamin $\mathrm{C}$. The size of the packaging containers affected the physicochemical changes in the strawberries. The treatment influenced the physico-chemical changes in the strawberries, such as the rate of respiration and vitamin $\mathrm{C}$ levels. The best packaging size was the smallest size $\left(K_{1}\right) K_{2}$ and $K_{3}$ packaging container sizes. This is indicated by the lowest weight loss variable, with the value of $0.20 \%$, the lowest value of respiration rate $\left(20.61 \mathrm{CO}_{2} /\right.$ $\mathrm{kg} /$ hour$)$, the highest vitamin C content $(72.89 \mathrm{mg} / 100 \mathrm{~g})$, while in the organoleptic test, the smallest container size resulted in the highest score in fruit colour, container size has a score highest in the observation of fruit color, fruit appearance and fruit aroma. Observation of the shelf life of strawberries showed that the container size of $\mathrm{K}_{1}$ (the smallest) had an average shelf life better than $K_{2}$ and $K_{3}$. $K_{1}$ container size produced a shelf life average of 4 days while $K_{2}$ container size produce a shelf life average of 3,4 days. The shortest shelf life average was recorded in the $\mathrm{K}_{3}$ container size with a value of 3,2 days. It is concluded that the shelf life of strawberries in a packaging container at atemperature of $28-30^{\circ} \mathrm{C}$ can be as long as 4 days.
\end{abstract}

Keywords: strawberies, type of plastic mica, number of pieces, shelf life

\section{PENDAHULUAN}

Stroberi (Fragaria sp.) merupakan salah satu jenis buah-buahan yang memiliki nilai ekonomi tinggi. Menurut Budiman \&
Saraswati (2008) dalam Nurrohmah \& Suketi (2011) petani di Indonesia, khususnya di daerah dataran tinggi telah melakukan budidaya stroberi secara 


\section{YONATHAN CHRISTIAN SIMATUPANG et al. Pengaruh Ukuran Wadah Kemasan...}

komersial. Produksi buah yang sampai sekarang belum dapat memenuhi permintaan pasar ini memiliki harga jual yang cukup tinggi.

Menurut Olias et al. (2001) dalam Hutajulu et al. (2018) permasalahan yang sering muncul pada saat penanganan pascapanen adalah masalah mekanis, fisiologis, dan serangan penyakit. Kualitas stroberi sangat ditentukan oleh penampilan luar, kekerasan dan rasa. Faktor utama dalam menjaga kualitas buah stroberi adalah ketepatan waktu panen dan penanganan pascapanen yang tepat sehingga memerlukan penanganan khusus pada saat panen dan pascapanen.

Pengemasan merupakan sistem yang terkoordinasi untuk menyiapkan barang menjadi siap untuk ditransportasikan, didistribusikan, disimpan, dijual, dan dipakai. Adanya wadah atau pembungkus dapat membantu mencegah atau mengurangi kerusakan, melindungi produk yang ada di dalamnya, melindungi dari bahaya pencemaran serta gangguan fisik (gesekan, benturan, getaran) (Mareta \& Awam, 2011).

Dari permasalahan yang ada dilakukan sebuah penelitian penanganan pascapanen buah stroberi yang mudah rusak, bertujuan untuk memperpanjang umur simpan buah stroberi dengan menggunakan berbagai jenis ukuran wadah kemasan plastik mika. Buah stroberi dikemas dengan ukuran wadah kemasan yang berbeda memakai jumlah buah yang sama dan disimpan pada suhu ruang.

\section{BAHAN DAN METODE}

Penelitian ini dilaksanakan di Laboratorium Ekofisiologi dan Laboratorium Agronomi dan Hortikultura, Fakultas Pertanian Universitas Udayana, Denpasar pada bulan Juni 2019 sampai dengan Juli 2019. Alat - alat yang digunakan dalam penelitian ini yaitu, kemasan mika GX4 (8x14 cm), GX3 $(10 \times 17 \mathrm{~cm}), 2 \mathrm{~A}(15 \times 20 \mathrm{~cm})$, penetrometer, timbangan digital, kamera digital, thermometer, plastik white stretch film, gelas ukur, kertas saring, dan alat labolatorium lainnya. Bahan yang digunakan yaitu buah stroberi segar yang didapatkan langsung dari kebun stroberi. Selain itu bahan kimia yang digunakan dalam penelitian adalah Fungisida, $\mathrm{Ca}(\mathrm{OH})_{2}$ jenuh, $\mathrm{NaOH} 0,05 \mathrm{~N}, \mathrm{NaOH} 0,01$ $\mathrm{N}, \mathrm{HCl} 0,05 \mathrm{~N}$, indikator fenolftalein, amilum dan iod 0,01 $\mathrm{N}$.

Penelitian menggunakan rancangan acak lengkap (RAL) dengan perlakuan tunggal yaitu perlakuan ukuran wadah kemasan mika. Ukuran wadah kemasan 
mika menggunakan 3 jenis ukuran kemasan mika yaitu, $\mathrm{K}_{1}=$ wadah kemasan mika GX4 (8x14 cm), $\mathrm{K}_{2}=$ wadah kemasan mika GX3 $(10 \times 17 \mathrm{~cm}), \mathrm{K}_{3}=$ wadah kemasan mika 2A $(15 \times 20 \mathrm{~cm})$. Masingmasing ukuran wadah kemasan mika memiliki jumlah buah yang sama yaitu 15 buah. Masing-masing perlakuan diulang sebanyak 9 kali sehingga diperoleh 27 unit percobaan.

Persiapan dimulai dengan pengambilan buah stroberi yang diperoleh dari kebun petani di Desa Pancasari, Kecamatan Buleleng. Buah stroberi dicuci dengan air mengalir untuk menghilangkan kotoran yang menempel dipermukaan kulit buah kemudian direndam menggunakan air yang dicampur dengan larutan fungisida lalu dikeringkan sebelum dikemas. Buah dikemas menggunakan kemasan mika dengan ukuran dan jumlah buah yang sudah ditentukan. Kemudian kemasan mika yang sudah terisi buah stroberi dibungkus kembali menggunakan plastik white stretch film.

Variabel pengamatan yang diamati adalah susut bobot, tingkat kekerasan buah, laju respirasi, kadar vitamin $\mathrm{C}$, uji organoleptik, umur simpan buah. Data yang diperoleh dianalisis dengan analisis of varian (ANOVA). Apabila didapatkan perbedaan nyata maka dilanjutkan dengan uji BNT 5\%.

\section{HASIL DAN PEMBAHASAN}

Hasil sidik ragam menunjukkan bahwa perlakuan jenis ukuran wadah kemasan $(\mathrm{K})$ berpengaruh tidak nyata $(\mathrm{P} \geq$ $0,05)$ terhadap variabel pengamatan susut bobot pada pengamatan 0, 2, 3, dan 4 HSP. Hasil ini disebabkan karena susut bobot buah yang terjadi pada ukuran wadah kemasan baik itu $\mathrm{K}_{1}, \mathrm{~K}_{2}$, dan $\mathrm{K}_{3}$ berbeda tidak nyata. Hasil sidik ragam menunjukkan bahwa perlakuan jenis ukuran wadah kemasan berpengaruh tidak nyata $(\mathrm{P} \geq 0,05)$ terhadap variabel pengamatan tingkat kekerasan buah pada pengamatan 0, 2, 3, dan 4 HSP. Hasil ini disebabkan karena tingkat kekerasan buah yang terjadi pada ukuran wadah kemasan baik itu $\mathrm{K}_{1}, \mathrm{~K}_{2}$, dan $\mathrm{K}_{3}$ tidak nyata. Hasil sidik ragam menunjukkan bahwa jenis ukuran wadah kemasan (K) berpengaruh sangat nyata $(\mathrm{P}<0,01) \quad$ terhadap jenis variabel pengamatan laju respirasi. Jenis ukuran wadah kemasan berpengaruh sangat nyata pada pengamatan 0, 2, 3, dan 4 HSP. Hasil sidik ragam untuk perhitungan kadar vitamin $\mathrm{C}$ menunjukkan jenis ukuran wadah kemasan $(\mathrm{K})$ berpengaruh tidak nyata $(\mathrm{P} \geq 0,05)$ pada pengamatan 0 HSP dan 
YONATHAN CHRISTIAN SIMATUPANG et al. Pengaruh Ukuran Wadah Kemasan...

berpengaruh nyata $(\mathrm{P}<0,05)$ pada 3 , dan 4 HSP. Pada uji organoleptik jenis pengamatan 2, 3, dan 4 HSP. Pengaruh ukuran wadah kemasan $\mathrm{K}_{1}$ lebih disukai perlakuan jenis ukuran wadah kemasan dibandingkan jenis ukuran wadah kemasan terhadap kadar vitamin $\mathrm{C}$ dapat dilihat pada $\quad \mathrm{K}_{2}$ dan $\mathrm{K}_{3}$. Hal ini dikarenakan jenis ukuran hasil uji beda yaitu jenis ukuran wadah wadah $\mathrm{K}_{1}$ memiliki skor tertinggi dalam kemasan $\mathrm{K}_{1}$ menunjukkan hasil berbeda segala aspek pengamatan, baik itu warna nyata dengan $\mathrm{K}_{2}$ dan $\mathrm{K}_{3}$ pada pengamatan 2, buah, penampakan buah dan aroma buah

Tabel 1. Signifikansi Pengaruh Perlakuan Jenis Ukuran Plastik Kemasan terhadap Variabel Pengamatan

\begin{tabular}{|c|c|c|}
\hline No. & Variabel & $\mathrm{K}$ \\
\hline \multirow[t]{4}{*}{1} & Susut bobot & \\
\hline & 0 HSP & ns \\
\hline & $2 \mathrm{HSP}$ & ns \\
\hline & 3 HSP & ns \\
\hline \multirow[t]{4}{*}{2} & $4 \mathrm{HSP}$ & ns \\
\hline & Kekerasan buah & \\
\hline & 0 HSP & ns \\
\hline & $2 \mathrm{HSP}$ & ns \\
\hline \multirow{4}{*}{3} & 3 HSP & ns \\
\hline & $4 \mathrm{HSP}$ & ns \\
\hline & Laju respirasi & \\
\hline & 0 HSP & $* *$ \\
\hline \multirow{5}{*}{4} & 2 HSP & $* *$ \\
\hline & $3 \mathrm{HSP}$ & $* *$ \\
\hline & $4 \mathrm{HSP}$ & $* *$ \\
\hline & Kandungan vitamin $\mathrm{C}$ & \\
\hline & 0 HSP & ns \\
\hline \multirow[t]{4}{*}{5} & $2 \mathrm{HSP}$ & $*$ \\
\hline & 3 HSP & $*$ \\
\hline & $4 \mathrm{HSP}$ & $*$ \\
\hline & Umur Simpan Buah & $* *$ \\
\hline & Keterangan : ns & : berpengaruh tidak nyata $(\mathrm{P} \geq 0,05)$ \\
\hline & $*$ & : berpengaruh nyata $(\mathrm{P}<0,05)$ \\
\hline & $* *$ & : berpengaruh sangat nyata $(\mathrm{P}<0,01)$ \\
\hline & HSP & : hari setelah perlakuan \\
\hline
\end{tabular}

Hasil sidik ragam menunjukkan kemasan $(\mathrm{K})$ berpengaruh tidak nyata $(\mathrm{P} \geq$ bahwa perlakuan jenis ukuran wadah 0,05) terhadap variabel pengamatan susut 
bobot. Hasil uji beda pada 0, 3, dan 4 HSP menunjukkan hasil berbeda tidak nyata. Bisa dilihat pada Tabel 2 jenis ukuran wadah kemasan $\mathrm{K}_{3}$ memiliki presentase susut bobot tertinggi pada pengamatan $4 \mathrm{HSP}$.

Tabel 2. Pengaruh Perlakuan Jenis Ukuran Wadah Kemasan terhadap Susut Bobot Buah Stroberi (\%) pada 0, 2, 3 dan 4 HSP

\begin{tabular}{|c|c|c|c|c|}
\hline Perlakuan Kemasan (K) & $0 \mathrm{HSP}$ & 2 HSP & $3 \mathrm{HSP}$ & $4 \mathrm{HSP}$ \\
\hline K1 & $0,20 \mathrm{a}$ & $0,46 \mathrm{a}$ & $1,00 \mathrm{a}$ & $1,33 \mathrm{a}$ \\
\hline $\mathrm{K} 2$ & $0,24 \mathrm{a}$ & $0,55 \mathrm{a}$ & $1,05 \mathrm{a}$ & $1,69 \mathrm{a}$ \\
\hline K3 & $0,25 \mathrm{a}$ & $0,52 \mathrm{a}$ & $1,00 \mathrm{a}$ & $1,76 \mathrm{a}$ \\
\hline $\mathrm{BNT} 5 \%$ & $\mathrm{~ns}$ & $\mathrm{~ns}$ & $\mathrm{~ns}$ & ns \\
\hline
\end{tabular}

Keterangan : angka yang diikuti huruf yang sama pada perlakuan dan kolom yang sama menunjukkan berbeda tidak nyata pada uji beda nyata terkecil (BNT) taraf $5 \%$.

Hasil sidik ragam menunjukkan diamati pada 4 HSP berbeda tidak nyata bila bahwa perlakuan jenis ukuran wadah dibandingkan dengan jenis ukuran wadah kemasan berpengaruh tidak nyata $(\mathrm{P} \geq 0,05)$ terhadap variabel pengamatan tingkat $\mathrm{K}_{3}$. Hasil uji BNT pada Tabel 3 kekerasan buah. Jenis ukuran wadah $\mathrm{K}_{2}$ yang menunjukkan hasil berbeda tidak nyata pada 0,2 dan 3 HSP.

Tabel 3. Pengaruh Perlakuan Jenis Ukuran Wadah Kemasan terhadap Tingkat Kekerasan Buah Stroberi (mm/100gram/detik) pada 0, 2, 3 dan 4 HSP

\begin{tabular}{|c|c|c|c|c|}
\hline Perlakuan Kemasan (K) & $0 \mathrm{HSP}$ & $2 \mathrm{HSP}$ & $3 \mathrm{HSP}$ & 4 HSP \\
\hline K1 & $1,27 \mathrm{a}$ & $1,05 \mathrm{a}$ & $0,69 \mathrm{a}$ & $0,46 \mathrm{a}$ \\
\hline $\mathrm{K} 2$ & $1,32 \mathrm{a}$ & $1,13 \mathrm{a}$ & $0,69 \mathrm{a}$ & $0,29 \mathrm{a}$ \\
\hline K3 & $1,35 \mathrm{a}$ & $0,93 \mathrm{a}$ & $0,82 \mathrm{a}$ & $0,56 \mathrm{a}$ \\
\hline BNT 5\% & ns & ns & $\mathrm{ns}$ & $\mathrm{ns}$ \\
\hline
\end{tabular}

Keterangan : angka yang diikuti huruf yang sama pada perlakuan dan kolom yang sama menunjukkan berbeda tidak nyata pada uji beda nyata terkecil (BNT) taraf $5 \%$. 
YONATHAN CHRISTIAN SIMATUPANG et al. Pengaruh Ukuran Wadah Kemasan...

Hasil sidik ragam menunjukkan bahwa presentase laju respirasi tertinggi ditunjukkan oleh jenis ukuran wadah kemasan $\mathrm{K}_{3}$ yaitu $55,94 \mathrm{mg} / \mathrm{kg} / \mathrm{jam}$ pada 2 HSP. Jenis ukuran wadah kemasan (K) berpengaruh sangat nyata $(\mathrm{P}<0,01)$ terhadap jenis variabel pengamatan laju respirasi. Jenis ukuran wadah kemasan $\mathrm{K}_{1}$ berbeda nyata dengan $\mathrm{K}_{3}$ dan berbeda tidak nyata dengan $\mathrm{K}_{2}$ pada pengamatan 0 HSP. Jenis ukuran wadah kemasan baik itu $\mathrm{K}_{1}, \mathrm{~K}_{2}$, dan $\mathrm{K}_{3}$ pada tabel 4 menunjukkan hasil berbeda nyata pada pengamatan $2 \mathrm{HSP}$. Jenis ukuran wadah kemasan $\mathrm{K}_{2}$ dan $\mathrm{K}_{3}$ berbeda tidak nyata pada 3 dan 4 HSP. Jenis ukuran wadah kemasan $\mathrm{K}_{1}$ berbeda nyata dengan $\mathrm{K}_{2}$ dan $\mathrm{K}_{3}$ pada pengamatan 3 dan 4 HSP.

Tabel 4. Pengaruh Perlakuan Jenis Ukuran Wadah Kemasan terhadap Laju Respirasi Buah Stroberi (mg/kg/jam) pada 0, 2, 3 dan 4 HSP

\begin{tabular}{|c|c|c|c|c|}
\hline Perlakuan Kemasan (K) & 0 HSP & $2 \mathrm{HSP}$ & $3 \mathrm{HSP}$ & 4 HSP \\
\hline K1 & $34,23 \mathrm{~b}$ & $31,51 \mathrm{c}$ & $20,61 \mathrm{~b}$ & $30,40 \mathrm{~b}$ \\
\hline K2 & $40,87 \mathrm{ab}$ & $40,72 \mathrm{~b}$ & 43,49 a & $39,24 \mathrm{a}$ \\
\hline K3 & $47,02 \mathrm{a}$ & $55,94 \mathrm{a}$ & $44,74 \mathrm{a}$ & $42,46 \mathrm{a}$ \\
\hline BNT 5\% & 7,0 & 5,69 & 4,84 & 4,40 \\
\hline
\end{tabular}

Keterangan : angka yang diikuti huruf yang sama pada perlakuan dan kolom yang sama menunjukkan berbeda tidak nyata pada uji beda nyata terkecil (BNT) taraf 5\%.

Hasil sidik Ragam untuk perhitungan kādar Vitamin C menunjukkan jenis ukuran wadah kemasan $(\mathrm{K})$ berpengaruh nyata $(\mathrm{P}<0,05)$ pada variabel pengamatan kadar vitamin C. Jenis ukuran wadah kemasan $\mathrm{K}_{1}$ pada_Tabel 5 menunjukkan hasil berbeda nyata dengan $\mathrm{K}_{3}$ dan berbeda tidak nyata dengan $\mathrm{K}_{2}$ pada pengamatan 0 HSP. Terlihat presentase kadar vitamin $\mathrm{C}$ tertinggi ditunjukkan oleh jenis ukuran wadah kemasan $\mathrm{K}_{1}$ dengan nilai $72,89 \mathrm{mg} / 100 \mathrm{~g}$. Hasil sidik ragam jenis ukuran wadah kemasan $\mathrm{K}_{2}$ dan $\mathrm{K}_{3}$ tidak berpengaruh nyata pada pengamatan 2 HSP, 3 HSP maupun 4 HSP. Jenis ukuran wadah kemasan $\mathrm{K}_{2}$ dan $\mathrm{K}_{3}$ berbeda tidak nyata pada 3 dan 4 HSP. Jenis ukuran wadah kemasan $\mathrm{K}_{1}$ berbeda nyata dengan $K_{2}$ dan $K_{3}$ pada pengamatan 3 dan 4 HSP. 
Agrotrop : Journal on Agriculture Science, 11 (1): 50 - 62 (2021)

Tabel 5. Pengaruh Perlakuan Jenis Ukuran Wadah Kemasan terhadap Kadar Vitamin C Buah Stroberi (mg/100g) pada 0, 2, 3 dan 4 HSP

\begin{tabular}{|c|c|c|c|c|}
\hline Perlakuan Kemasan (K) & $0 \mathrm{HSP}$ & 2 HSP & $3 \mathrm{HSP}$ & 4 HSP \\
\hline $\mathrm{K} 1$ & $53,80 \mathrm{a}$ & $46,82 \mathrm{a}$ & $72,89 \mathrm{a}$ & $49,62 \mathrm{a}$ \\
\hline $\mathrm{K} 2$ & $25,05 \mathrm{ab}$ & $13,50 \mathrm{~b}$ & $14,59 \mathrm{~b}$ & $10,65 \mathrm{~b}$ \\
\hline K3 & $12,85 \mathrm{~b}$ & $12,59 \mathrm{~b}$ & $13,37 \mathrm{~b}$ & $9,46 \mathrm{~b}$ \\
\hline BNT 5\% & 38,73 & 29,01 & 4,84 & 32,79 \\
\hline
\end{tabular}

Keterangan : angka yang diikuti huruf yang sama pada perlakuan dan kolom yang sama menunjukkan berbeda tidak nyata pada uji beda nyata terkecil (BNT) taraf 5

Uji organoleptik ini dinilai kondisi masing-masing unit yang dinilai. berdasarkan tingkat kesukaan panelis Nilai atau skor yang diberikan pada masingterhadap warna buah, penampakan buah, dan masing panelis adalah 1-5 dengan kategori aroma buah. Tingkat kesukaan panelis penilaian sebagai berikut; 1. Sangat tidak bersifat fluktuasi selama masa simpan. Sifat suka, 2. Tidak suka, 3. Biasa, 4. Suka, 5. fluktuasi ini terjadi karena keberagaman Sangat suka. pendapat atau nilai yang diberikan terhadap

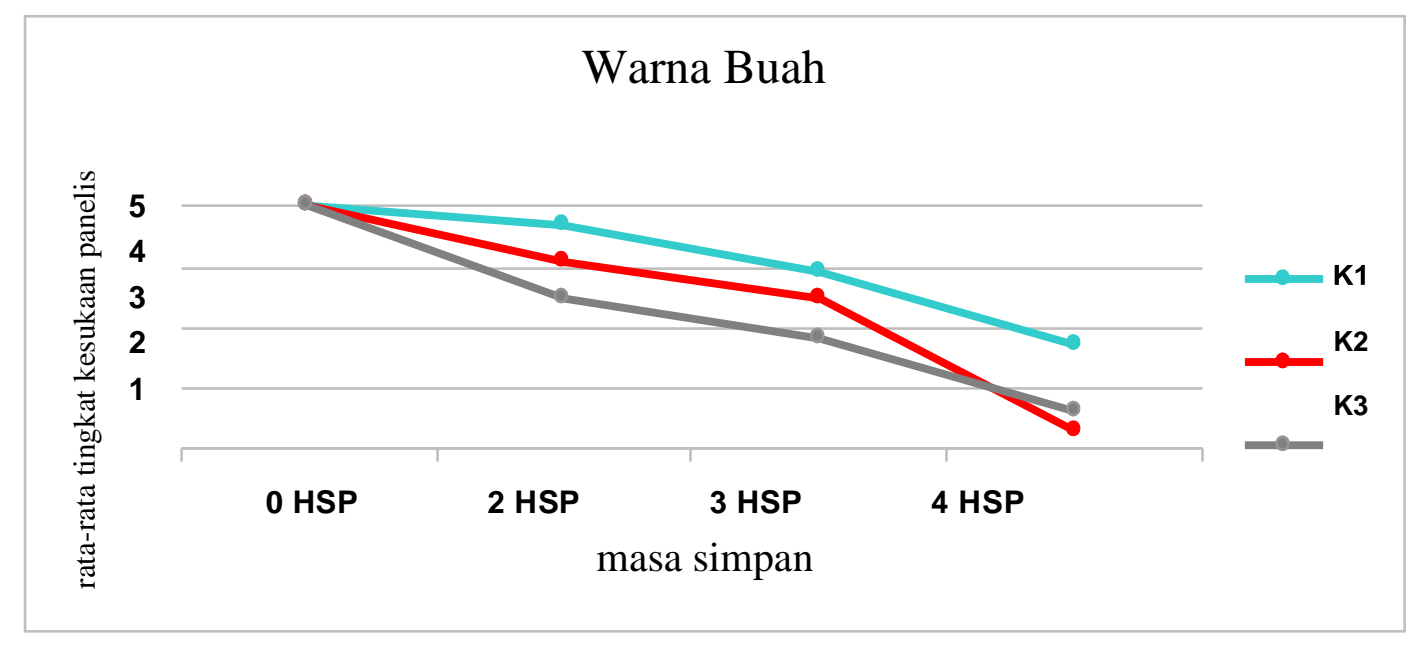

Gambar 1. Rata-rata Tingkat Kesukaan Panelis terhadap Warna Buah Stroberi 
YONATHAN CHRISTIAN SIMATUPANG et al. Pengaruh Ukuran Wadah Kemasan...

Hasil analisis Rata-rata tingkat dibandingkan dengan tingkat kesegaran buah kesukaan panelis terhadap warna buah yang berada pada jenis ukuran wadah adalah jenis ukuran wadah kemasan $\mathrm{K}_{1}$ kemasan $\mathrm{K}_{2}$ dan $\mathrm{K}_{3}$. Jenis ukuran wadah memiliki nilai atau skor tertinggi. Hal ini kemsan $K_{1}$ memiliki skor tertinggi pada disebabkan karena buah yang berada pada jenis ukuran wadah kemasan $\mathrm{K}_{1}$ memiliki setiap pengamatan baik pada 0 HSP maupun 2, 3 dan 4 HSP. tingkat kesegaran yang lebih tinggi

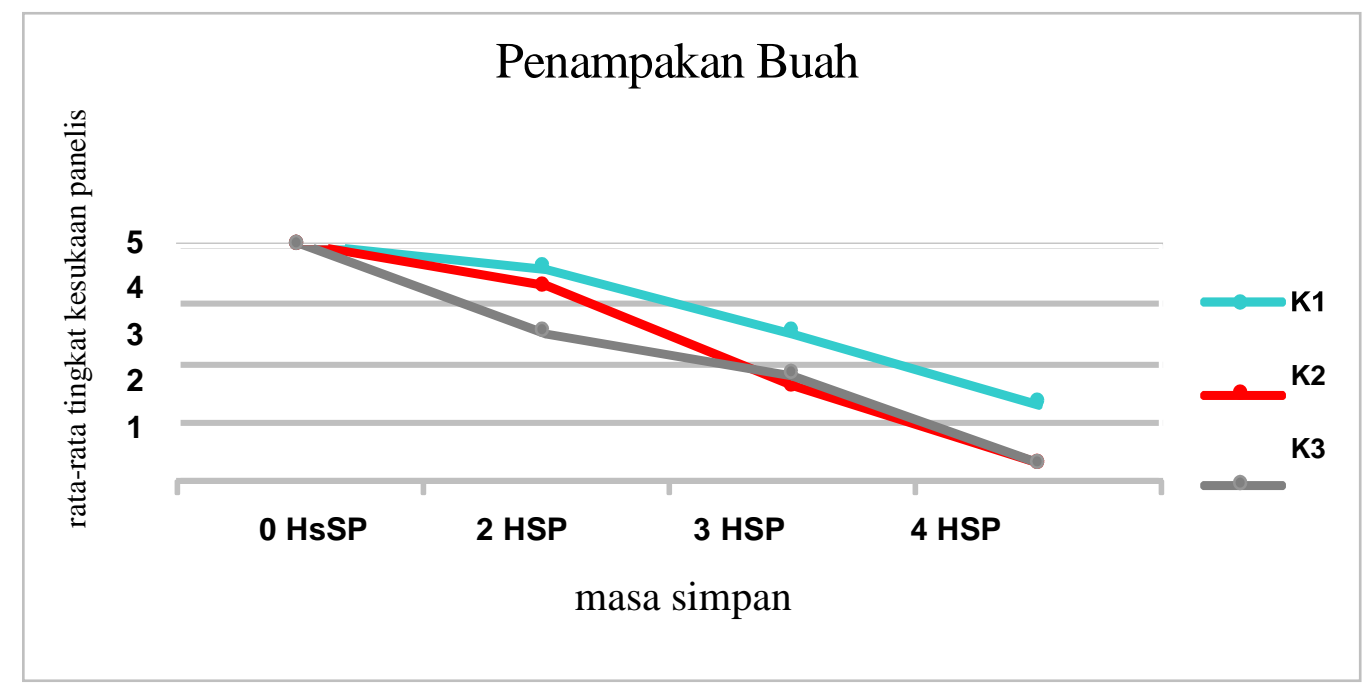

Gambar 2. Rata-rata Tingkat Kesukaan Panelis terhadap Penampakan Buah Stroberi

Hasil analisis Rata-rata tingkat yang ada di dalamnya. Semakin banyak buah kesukaan panelis terhadap penampakan yang terserang mikroorganisme maka buah adalah jenis ukuran wadah kemasan $\mathrm{K}_{1}$ tingkat kesukaan panelis terhadap memiliki nilai atau skor tertinggi penampakan buah pada jenis ukuran wadah dibandingkan dengan jenis ukuran wadah kemasan tersebut semakin rendah. Jenis kemasan $\mathrm{K}_{2}$ dan $\mathrm{K}_{3}$. Jenis ukuran wadah ukuran wadah kemasan $\mathrm{K}_{2}$ dan $\mathrm{K}_{3}$ sama-sama kemasan mempengaruhi seberapa besar memiliki skor yang paling rendah. serangaan mikroorganisme terhadap buah 


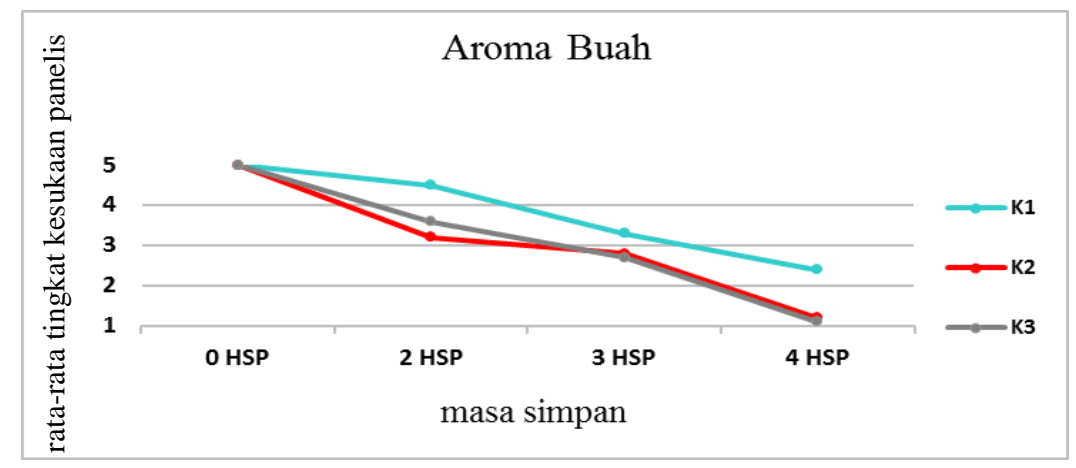

Gambar 3. Rata-rata Tingkat Kesukaan Panelis terhadap Aroma Buah Stroberi

Hasil analisis Rata-rata tingkat buah tersebut, serta dipengaruhi pula dari kesukaan panelis terhadap aroma buah jenis ukuran wadah kemasan. Skor penilaian adalah jenis ukuran wadah kemasan $\mathrm{K}_{1}$ paling rendah ditunjukkan pada jenis ukuran memiliki nilai atau skor tertinggi dibandingkan dengan jenis ukuran wadah kemasan $K_{2}$ dan $K_{3}$. Semakin rendah penilaian panelis terhadap jenis ukuran wadah kemasan di setiap pengamatan dipengaruhi oleh kualitas buah selama masa simpan. Dimana selama masa simpan buah akan mengalami kerusakan yang berhubungan dengan perubahan kimia pada wadah kemasan $\mathrm{K}_{3}$.

Umur simpan diukur secara visual dengan mengamati perubahan warna dan bentuk buah stroberi. Variabel pengamatan umur simpan buah menjadi tolak ukur kapan penelitian ini berakhir. Penelitian ini berakhir jika $65 \%$ buah sudah rusak atau hanya tersisa $35 \%$ buah yang masih layak di konsumsi.

Tabel 6. Pengaruh Perlakuan Jenis Ukuran Wadah Kemasan terhadap Umur Simpan Buah Stroberi pada 4 HSP

\begin{tabular}{lc} 
Perlakuan Kemasan $(\mathrm{K})$ & 4 HSP \\
\hline $\mathrm{K}_{1}$ & $4,0 \mathrm{a}$ \\
$\mathrm{K}_{2}$ & $3,4 \mathrm{~b}$ \\
$\mathrm{~K}_{3}$ & $3,2 \mathrm{~b}$ \\
\hline BNT 5\% & $* *$ \\
\hline
\end{tabular}

Keterangan : angka yang diikuti huruf yang sama pada kolom yang sama menunjukkan berbeda tidak nyata pada uji beda nyata terkecil (BNT) taraf $5 \%$.

Pengamatan umur simpan buah kemasan $\mathrm{K}_{1}$ memiliki rata-rata umur simpan stroberi menunjukkan jenis ukuran wadah yang lebih baik pada dibandingkan $\mathrm{K}_{2}$ dan 


\section{YONATHAN CHRISTIAN SIMATUPANG et al. Pengaruh Ukuran Wadah Kemasan...}

$\mathrm{K}_{3 .}$ Jenis ukuran wadah kemasan $\mathrm{K}_{1}$ memiliki rata-rata umur simpan 4 hari. Jenis ukuran wadah kemasan $\mathrm{K}_{2}$ memiliki rata-rata umur simpan 3,4 hari. Jenis ukuran wadah kemasan $\mathrm{K}_{3}$ memiliki rata-rata umur simpan 3,2 hari.

Berdasarkan dari hasil pengamatan pemberian perlakuan jenis ukuran wadah kemasan baik itu $\mathrm{K}_{1}, \mathrm{~K}_{2}$ dan $\mathrm{K}_{3}$ memberikan pengaruh terhadap kualitas dan umur simpan buah stroberi.

Susut bobot buah terus meningkat selama masa simpan. Susut bobot yang terus meningkat dipengaruhi oleh buah yang kehilangan air selama masa simpan. Hilangnya air pada buah disebabkan karena terjadinya respirasi. Hasil sidik ragam menunjukkan bahwa perlakuan jenis ukuran wadah kemasan (K) berpengaruh tidak nyata $(\mathrm{P} \geq 0,05)$ terhadap variabel pengamatan susut bobot.

Jenis ukuran wadah kemasan yang berbeda memberikan perbedaan terhadap volume ruang yang mengakibatkan perbedaan tingkat tinggi atau rendahnya gas $\mathrm{CO}_{2}$ yang diproduksi buah stroberi selama berada di dalam kemasan.

Laju respirasi merupakan faktor penting dalam menentukan umur simpan buah stroberi, semakin tinggi laju respirasi maka umur simpan akan semakin pendek pula. Hal ini disebabkan karena dalam tahapan ini buah akan menghasilkan $\mathrm{CO}_{2}$ yang tinggi sedangkan $\mathrm{O}_{2}$ kearah sebaliknya yaitu semakin mengecil. $\mathrm{CO}_{2}$ yang semakin tinggi mempengaruhi umur simpan buah stroberi. Respirasi pada buah merupakan proses biologis di mana oksigen diserap untuk membakar bahan-bahan organik dalam buah untuk menghasilkan energi dan diikuti oleh pengeluaran sisa pembakaran berupa $\mathrm{CO}_{2}$ dan $\mathrm{H}_{2} \mathrm{O}$. Air dan gas yang dihasilkan untuk memperoleh energi akan berupa panas dan mengalami penguapan yang menyebabkan penyusutan berat. Air yang dihasilkan ditranspirasikan dan jika tidak dikendalikan produk akan cepat menjadi layu (Ryall \& Lipton, 1972).

Laju respirasi yang meningkat menyebabkan suhu internal buah juga meningkat disebabkan panas (energi) yang dihasilkan dari respirasi. Suhu internal buah yang tinggi menyebabkan selisih antara tekanan uap lingkungan dan buah menjadi besar. Semakin besar selisih yang terjadi maka kecepatan laju perpindahan uap air akan semakin tinggi, sehingga berpengaruh terhadap nilai susut bobot yang besar (BenYehoshua \& Rodov, 1987).

Laju respirasi selain memiliki pengaruh terhadap variabel pengamatan susut bobot juga memiliki pengaruh 
terhadap variabel pengamatan tingkat kekerasan buah atau kelunakan buah. Buah stroberi tergolong buah Terjadinya kelunakan pada buah dikarenakan tipisnya lapisan dinding luar stroberi yang membuat buah stroberi rentan kehilangan banyak air dan menyebabkan buah stroberi menjadi layu.

Terlihat persentase kadar vitamin C tertinggi ditunjukkan oleh jenis ukuran wadah kemasan $\mathrm{K}_{1}$ yaitu $72,89 \mathrm{mg} / 100 \mathrm{~g}$. Dalam hal ini, laju respirasi juga berpengaruh terhadap kadar vitamin $\mathrm{C}$. Buah yang diberikan perlakuan kemasan memiliki laju respirasi yang lebih rendah dibandingkan buah yang tidak dikemas. Menurut Susanto \& Saneto (1994), menyebutkan bahwa penyimpanan dan pengolahan dapat mempengaruhi kandungan vitamin C. Penurunan kadar vitamin $\mathrm{C}$ pada sampel buah yang disimpan di suhu ruangan lebih signifikan karena pada suhu ruang, kondisi lingkungan tidak dapat dikendalikan seperti adanya panas dan oksigen, sehingga proses pematangan buah berjalan dengan sempurna (Sudarmadji et al., 1989)(Sudarmadji et al., 1989).

Pada pengamatan uji organoleptic jenis ukuran wadah kemasan $\mathrm{K}_{1}$ memiliki nilai skor tertinggi baik itu pada penilaian tingkat kesukaan panelis terhadap warna buah, penampakan buah, dan aroma buah. Jenis ukuran wadah kemasan yang mendapat nilai terendah diperoleh jenis ukuran wadah kemasan $\mathrm{K}_{3}$. Hal ini dikarenakan buah yang berada dalam kemasan $\mathrm{K}_{3}$ sudah tidak layak dikonsumsi dikarenakan warna, penampakan, dan kekerasannya yang sudah tidak memenuhi standar.

Pengamatan umur simpan diamati setiap harinya sampai buah stroberi mencapai persentase $65 \%$ dari seluruh buah di dalam masing-masing kemasan sudah rusak. Persentase umur simpan dari seluruh jenis ukuran wadah kemasan sama-sama berakhir pada 4 HSP dimana buah di dalam sudah mencapai $65 \%$ rusak. Menurut Wilson et al. (1999), umur simpan buah stroberi pada kondisi optimum yaitu dengan suhu $0^{\circ} \mathrm{C}$ dengan kelembaban RH 90-95\% adalah 5-7 hari.

\section{SIMPULAN}

Berdasarkan hasil penelitian, maka dapat disimpulkan beberapa hal yaitu penggunaan perlakuan jenis ukuran wadah kemasan memberikan pengaruh terhadap perubahan fisiko-kimia pada buah stroberi. Perlakuan kemasan berpengaruh terhadap susut bobot, tingkat kekerasan buah, laju 
YONATHAN CHRISTIAN SIMATUPANG et al. Pengaruh Ukuran Wadah Kemasan...

respirasi, uji organoleptik, kadar vitamin C dan umur simpan. Dalam hasil pengamatan diperoleh jenis kemasan yang memiliki penilaian terbaik adalah jenis ukuran wadah kemasan $\mathrm{K}_{1}$.Umur simpan buah stroberi dengan pemberian perlakuan berbagai macam jenis ukuran wadah kemasan pada suhu $28-30^{\circ} \mathrm{C}$ adalah 4 hari. Berdasarkan dari hasil penelitian yang sudah didapat, maka untuk mendapatkan kualitas dan umur simpan buah stroberi yang baik dianjurkan pemakaian jenis ukuran wadah kemasan $\mathrm{K}_{1}$ dengan jumlah 15 buah dalam satu kemasan. Untuk mendapatkan umur simpan yang lebih baik dianjurkan dengan penggunaan perlakuan suhu rendah dan perlakuan pascapanen lainnya agar dapat menghambat laju respirasi yang lebih baik.

\section{UCAPAN TERIMA KASIH}

Disampaikan ucapan terima kasih yang sebesar-besarnya kepada Tuhan Yang Maha Esa, Dosen Pembimbing, teman- teman dan seluruh pihak yang telah membantu jalannya penelitian ini.J_uga diucapkan terima kasih kepada Fakultas Pertanian Universitas Udayana atas fasilitas yang diberikan.

\section{DAFTAR PUSTAKA}

Ben-Yehoshua, S., \& Rodov, V. (1987). Transpiration and Water Stress.
Postharvest Physiology and Pathology of Vegetables.

Budiman, S., \& Saraswati, D. (2008). Berkebun Stroberi secara Komersial. Penebar Swadaya.

Hutajulu, E. D., Mahendra, M. S., \& Astawa, I. N. G. (2018). Pengaruh Berbagai Jenis Kemasan Terhadap Umur Simpan dan Perubahan Fisiko-Kimia pada Buah Stroberi (Fragaria sp.). Jurnal Agroekoteknologi Tropika (Journal of Tropical Agroecotechnology), 7(2), 211-219.

Mareta, D. T., \& Awam, S. N. (2011). Pengemasan Produk Sayuran Dengan Bahan Kemas Plastik Pada Penyimpanan Suhu Ruang Dan Suhu Dingin. MEDIAGRO, 7(1), 26-40. https://www.publikasiilmiah.unwahas .ac.id/index.php/Mediagro/article/do wnload/530/652

Nurrohmah, F. A., \& Suketi, K. (2011). Pengelolaan Pemupukan Stroberi di Vin's Berry Park, Cisarua, Lembang, Jawa Barat. IPB (Bogor Agricultural University).

Olias, J. M., Sanz, C., \& Perez, A. G. (2001). Postharvest Handling of Strawberries for Fresh Market. P. 209-227. In R. Nishakanen, and S.M. Jain (Eds).Crop Management and Postharvest Handling of Horticultural Product. Science Publisher, inc.

Ryall, A. L., \& Lipton, W. J. (1972). Handling, transportation, and storage of fruits and vegetables, volume 1 , vegetables and melons. AVI Pub. Co, .Westport, Connecticut.

Sudarmadji, S., Haryono, B., \& Suhardi. (1989). Analisis Bahan Makanan dan Pertanian.

Susanto, T., \& Saneto, B. (1994). Teknologi pengolahan hasil pertanian. Bina Ilmu.

Wilson, L. G., Boyette, M. D., \& Estes, G. A. (1999). Post Harvest Handling and 
Agrotrop : Journal on Agriculture Science, 11 (1): 50 - 62 (2021)

Cooling of Fresh Fruits, Vegetables and Flowers for Small Farms, Leaflets 800-804. 17. 